\title{
The role of encrusting coralline algae in the diets of selected intertidal herbivores
}

\author{
Gavin W. Maneveldt*, Deborah Wilby, Michelle Potgieter \& Martin G.J. Hendricks \\ Department of Biodiversity and Conservation Biology \\ University of the Western Cape \\ P. Bag X17 \\ Bellville 7535 \\ South Africa \\ * Correcsponding author: gmaneveldt@uwc.ac.za
}

Key words: encrusting coralline algae, diet, grazers, herbivory, organic content, rocky shore.

\begin{abstract}
Kalk Bay, South Africa, has a typical south coast zonation pattern with a band of seaweed dominating the mid-eulittoral and sandwiched between two molluscanherbivore dominated upper and lower eulittoral zones. Encrusting coralline algae were very obvious features of these zones. The most abundant herbivores in the upper eulittoral were the limpet, Cymbula oculus (10.4 $\pm 1.6 \mathrm{~m}^{-2}$; $201.65 \pm 32.68$ g.m $\left.\mathrm{m}^{-2}\right)$ and the false limpet, Siphonaria capensis $\left(97.07 \pm 19.92 \mathrm{~m}^{-2} ; 77.93 \pm 16.02\right.$ g.m $\mathrm{m}^{-2}$ ). The territorial gardening limpet, Scutellastra cochlear, dominated the lower eulittoral zone, achieving very high densities $\left(545.27 \pm 84.35 \mathrm{~m}^{-2}\right)$ and biomass (4630.17 \pm 556.13 g.m-2), and excluded all other herbivores and most seaweeds, except for its garden alga and the encrusting coralline alga, Spongities yendoi (35.93 $\pm 2.26 \%$ cover). For the upper eulittoral zone, only the chiton Acanthochiton garnoti $30.5 \pm 1.33 \%$ and the limpet $C$. oculus $2.9 \pm 0.34 \%$, contained encrusting coralline algae in their guts. The lower eulittoral zone limpet, Scutellastra cochlear also had a large percentage of encrusting coralline algae in its gut with limpets lacking gardens having higher $(45.1 \pm 1.68 \%)$ proportions of coralline algae in their guts than those with gardens $(25.6 \pm 0.8 \%)$. Encrusting coralline algae had high organic contents, similar to those of other encrusting and turfy algae, but higher organic contents than foliose algae. Radula structure, grazing frequencies as a percentage of the area grazed (upper eulittoral $73.25 \pm 3.60 \% \mathrm{~d}^{-1}$; lower eulittoral $46.0 \pm 3.29 \% \mathrm{~d}^{-1}$ ), and algae organic content provided evidence to support the dietary habits of the above herbivores. The data show that many intertidal molluscs are actively consuming encrusting coralline algae and that these seaweeds should be seen as an important food source.
\end{abstract}




\section{Introduction}

In South Africa there is a high level of seaweed endemism (Lüning, 1990; Stegenga et al., 1997), and large numbers of herbivores. These herbivores are important in the intertidal zone as they control the abundance and distribution of algae through their grazing activities (Branch, 1975; 1985). Much of the research on herbivore-algal interactions in South Africa has focused on grazing interactions involving fleshy seaweed (Branch, 1971; 1985). Although not common, encrusting coralline algae have been cited as important food sources for many intertidal herbivores (Steneck, 1982; 1985; Steneck \& Watling, 1982; Paine, 1984; Steneck et al., 1991; Fujita, 1992; Littler et. al., 1995; Raffaelli \& Hawkins, 1996; Littler \& Littler 2003) and a few local studies have shifted their research focus toward herbivore-algal interactions involving coralline algae (Keats et al., 1994b; Maneveldt, 1995).

Encrusting coralline algae are important occupiers of space in rocky marine intertidal environments (Adey \& McIntyre, 1973; Paine, 1984; Steneck, 1982; 1985; 1986; Dethier et al., 1991; Steneck et al., 1991; Keats \& Maneveldt, 1994; Keats et al., 1994a; b) and often become abundant in areas of intense herbivory (Adey \& McIntyre, 1973; Steneck, 1983; Breitburg, 1984; Sousa \& Connell, 1992; Dethier, 1994; Steneck \& Dethier, 1994). Despite their ubiquity, they are a poorly known group of seaweeds (Keats et al., 1994a). Nonetheless, they are a very obvious feature of the South African rocky intertidal with a few species occurring in high abundance (Stegenga et al., 1997).

The rocky intertidal of the South African south and west coasts has been divided into four zones: the Littorina zone (supralittoral fringe); the upper balanoid zone (upper eulittoral zone); the lower balanoid zone (mid-eulittoral zone); and the cochlear zone (lower eulittoral zone) (Branch \& Branch, 1988). Within the intertidal, a band of seaweed dominates the mid-eulittoral zone and is sandwiched between an herbivoredominated upper and lower eulittoral zones. In the upper eulittoral zone, a number of molluscan grazers are very abundant, feeding on a broad range of available seaweeds (Branch, 1971). Algal diversity generally increases down the shore. In the lower eulittoral zone, however, this diversity is abruptly reduced because a dense band of territorial, gardening limpets Scutellastra cochlear, exclude not only other herbivores, but all seaweed except for their gardens of fine red, turfy algae (Gelidium micropterum or Herposiphonia heringii) and for two encrusting coralline red algae (Spongites yendoi and Leptophytum foveatum) (Branch, 1975; 1976; Branch \& Griffiths, 1988; Keats et al., 1994b). The degree to which many of these grazers feed on a specific seaweed is relatively unknown and more so, the role of encrusting coralline algae, that form such a conspicuous feature of the intertidal, has not been addressed. In this study we asked: 1 ) which algae are readily available to grazers and what are their nutritional qualities? 2) are any grazers incorporating coralline algae in their diets? and if so 3) how often are coralline surfaces being grazed? 


\section{Materials and methods \\ Study site}

The study site, Kalk Bay ( $34^{\circ} 8^{\prime} \mathrm{S}, 18^{\circ} 27^{\prime} \mathrm{E}$ ), is situated within False Bay, South Africa. This site has a typical south coast zonation pattern (Branch \& Branch 1988). A number of molluscan grazers (the true limpet, Cymbula oculus, the false limpet, Siphonaria capensis and the winkle, Oxystele variegata) and barnacles (Tetraclita serrata and Octomeris angulosa) occur abundantly within the upper eulittoral zone. The territorial, gardening limpet, Scutellastra cochlear dominates the lower eulittoral zone.

\section{Algal availability and nutritional quality}

Algal availability and their nutritional quality was estimated by determining: 1) natural algal cover; and 2) relative organic content.

Algal cover was determined along three randomly chosen transect lines running down the shore. Five quadrats $\left(0.3 \mathrm{X} 0.3=0.09 \mathrm{~m}^{2}\right)$ placed at regular intervals along each transect were used to estimate algal cover. To determine cover of encrusting algae, that of the upright fleshy algae was estimated first and then they were removed to obtain the estimates of encrusting algae. Using this method, summed cover estimates for both encrusting and upright algae may exceed $100 \%$.

Organic content is often represented as a proportion of the dry weight. Algae, however, vary greatly in their water content which has a diluting effect and no-doubt affects the nutrient value to herbivores. We therefore assessed the organic content of algae on a 'per-bite basis' by representing organic content as a proportion of wet weight, i.e ash-free dry weight as a proportion of wet weight (AFDW:WW). Samples for nutrient analysis comprised algae found throughout the intertidal including those that were not abundant (Table 1). Algae were first hydrated in seawater for $30 \mathrm{~min}$ prior to examination and then blotted dry to remove excess water. Samples were burnt in a furnace at $450^{\circ} \mathrm{C}$ for 16 hours.

\section{Dietary incorporation of coralline algae}

The incorporation of coralline algae into the diet was assessed via four determinations: 1) the densities and biomass of commonly observed invertebrates; 2) a comparison of the grazing frequencies experienced within each of the two herbivore dominated zones; 3) an analysis of gut contents of common molluscan herbivores; and 4) examination of the radula of those molluses shown to graze corallines.

Invertebrate densities and biomass were determined along three randomly chosen transect lines running down the shore. Five quadrats $\left(0.5 \mathrm{X} 0.5=0.25 \mathrm{~m}^{2}\right)$ placed at regular intervals along each transect were used to calculate densities. Animals from these quadrats were collected and brought back to the lab for biomass determinations. 
Grazing frequency was measured in the field by recording the number of graphite dots removed (sensu Steneck et al., 1991) from the surfaces of the two dominant encrusting coralline algae found within both the upper and lower eulittoral zones (n $=25$ crusts per species per zone). A series of $4 \mathrm{X} 4$ dots, $2 \mathrm{~mm}$ in diameter and 10 $\mathrm{mm}$ apart (area per treatment: $3 \mathrm{X} 3 \mathrm{~cm}=9 \mathrm{~cm}^{2}$ ), was used to estimate the relative grazing frequencies experienced by encrusting coralline algae. The number of dots removed by limpets was recorded daily for two days and expressed as grazing frequency per day. Ungrazed dots persist for several days on the coralline surface.

For gut contents analysis, the foregut of 20 individuals from each of the molluscan herbivore species observed (see Table 1) was dissected. The foregut was then extruded into a $5 \mathrm{ml}$ vile containing $1 \mathrm{ml}$ distilled water, agitated, and then emptied into an ice cube tray with $20 \mathrm{X} 20 \mathrm{~mm}$ compartments. This method was effective at distributing the gut contents evenly in the ice cube tray compartments. Using a stereo-microscope equipped with an eyepiece quadrat divided into 100 squares, the percentage of coralline algae was estimated; coralline algal cells are easily discernable from those of fleshy algae. Coralline 'chalk' from the posterior part of the gut was not included as this has been shown to produce inaccurate measures of actual consumption; 'indigestible' material is known to persist for a long time in the posterior part of the gut.

The radulae of herbivores found to contain coralline algae in their guts were then removed and a representative radula from each of these herbivore species was examined and photographed under a scanning electron microscope (SEM). Using Xray analysis, the radulae were also scanned to determine the concentrations and relative amounts of hardening agents in the functional teeth.

\section{Statistical analyses}

Unless otherwise stated, all data are presented as means \pm standard errors. Grazing frequencies in the upper and lower eulittoral zones were compared using a MannWhitney nonparametric test (Mann-Whitney, 1947).

\section{Results}

\section{Algal availability and nutritional quality}

Foliose algal cover was greatest in the lower $(39.67 \pm 4.54 \%, \mathrm{n}=15)$ than in the upper $(14.54 \pm 4.65 \%, \mathrm{n}=15)$ eulittoral zone. In both zones the most abundant alga was an encrusting alga, occupying similar proportions of the substratum. The fleshy red alga Hildenbrandia lecanellierii dominated the upper eulittoral, while the coralline red alga Spongites yendoi dominated the lower eulittoral zone (Figure 1). In the upper eulittoral zone, a large percentage of the primary substratum was free of algae as denoted by the "bare rock/biofilm" component.

Organic content (as a proportion of the algal wet weight) was highly variable among the different algae tested. Foliose algae (Gigartina polycarpa, Sarcothalia stiriata, 
Ulva capensis and Enteromorpha intestinalis), with the exception of Porphyra capensis, had much lower organic content than both encrusting (S. yendoi; Leptophytum ferox, Ralfsia verrucosa and $H$. lecanellierii) and turfy algae (Gelidium micropterum and G. pristoides) (Figure 2).

\section{Dietary incorporation of coralline algae}

A greater number of different invertebrate species was observed for the upper than the lower eulittoral zone (Table 2). The invertebrate densities and biomass in the upper eulittoral zone was highly variable with barnacles ( $T$. serrata) characteristically occurring in high numbers and obtaining high biomass. Although the false limpet $S$. capensis occurred in high numbers, this tiny limpet in no way matched the biomass of the larger true limpet, $C$. oculus. The lower eulittoral zone comprised only one limpet, $S$. cochlear which achieved very high densities and biomass (Table 2).

Grazing frequency (as a percentage of dots grazed $\mathrm{d}^{-1}$ ) on encrusting coralline algae was significantly higher in the upper than in the lower eulittoral zone $(\mathrm{U}=82.0, \mathrm{Z}=$ 4.47, $\mathrm{P}<0.01, \mathrm{n} 1=25, \mathrm{n} 2=25$ ) (Figure 3).

Of the herbivores examined (Table 1), only three were found to contain coralline algae in their guts (Figure 4). Both the limpet $S$. cochlear and the chiton Acanthochiton garnoti contained a substantial percentage of coralline algae in their guts and were probably both actively grazing these algae. Scutellastra cochlear individuals without gardens, however, had much greater proportions of coralline algae in their guts than those individuals with gardens (Figure 4). By contrast, the limpet $C$. oculus had a small percentage of coralline algae in its gut.

The radula structure of the three herbivores found to contain coralline algae in their guts (Figures $5 \& 6$ ) differed to varying degrees in their design, tooth structure and elemental concentrations of their functional teeth (see Steneck \& Watling, 1982 for a description of different moluscan radulae). Limpets (S. cochlear and C. oculus) have a docoglossan radula, while chitons (A. garnoti) have a polyplacophoran radula that is more effective at grazing hard substrata. Although the design of the two limpets are similar ( 3 marginals : 3 laterals : 1 central : 3 laterals : 3 marginals), they differed with respect to the shape of their teeth (Figure 5). Scutellastra cochlear's teeth have rounded distal ends while those of $C$. oculus are pointed. X-ray analysis showed that both limpets have iron concentrated only in their lateral teeth with greater concentrations (indicated by the intensity of the scan) at their distal ends (Figure 5). The chiton, A. garnoti, has two dominant teeth bearing three cusps (Figure 6). Chitons only use four marginal teeth during grazing, the two dominant teeth serving to excavate the substratum (Fretter \& Graham, 1994). 


\section{Discussion}

Both the upper and lower eulittoral zones at Kalk Bay have relatively large densities and biomass of herbivores that have reduced the algal cover and diversity to but a few species (Branch, 1971; 1975; 1980; 1985). Encrusting algae are the only group of algae that are able to survive the high grazing pressures that occur within both zones. This is not surprising, as many studies have shown that encrusting algae, and corallines in particular, thrive under, and even require, intense herbivory (Paine \& Vadas, 1969; Steneck, 1982; 1983; Breitburg, 1984; Sousa \& Connell, 1992; Dethier, 1994; Steneck \& Dethier, 1994).

The Kalk Bay intertidal is capable of supporting high herbivore densities and biomass despite the low algal cover. The dominant algae within both zones are high in organic content. Within the lower eulittoral, the territorial limpet, S. cochlear, appears to rely heavily on a diet of encrusting coralline algae despite many limpets having their own algal gardens. Branch (1980) stated that production and energy content of $S$. yendoi (as Lithothamnion) is so low that it cannot alone support the energy needs of $S$. cochlear. Branch (1980) further stated that the gardens of fine red algae are vital for the densely packed $S$. cochlear and although they often form only a small fringe around each animal, their production and energy contents are high. Our results show that $S$. yendoi is similarly high in organic content when compared to the garden alga, G. micropterum, and this explains why $S$. cochlear lacking gardens, consume proportionately more coralline algae than those limpets with gardens. It may be that the coralline and the garden alga are fulfilling different requirements and that $S$. cochlear with gardens are maintaining a mixed diet of algae. This, however, needs to be evaluated through further studies. Recent work by M. E. Hay and Q. E. Kappel (pers. comm.) has, however, also shown that organic content is high in many corallines relative to many fleshy algae.

Within the upper eulittoral zone, the large numbers of grazers may be supplementing their diets with the abundant encrusting, fleshy red alga, $H$. lecanellierii which is also high in organic content. Grazers typically consume a variety of plant matter and within the upper eulittoral zone, where algae are low in abundance, this probably comprises a mixture of predominantly microscopic algae, algal spores and larvae. An examination of the grazing frequencies experienced by encrusting corallines clearly demonstrates the high grazing pressures exerted within the upper eulittoral zone.

In the upper eulittoral, only the chiton A. garnoti and the limpet $C$. oculus were found to contain coralline algae in their guts. Chitons are known to be formidable grazers, many of them including large proportions of coralline algae in their diets (Steneck \& Watling, 1982; Littler et al., 1995; Littler \& Littler, 2003). Similarly, A. garnoti appears to be actively grazing the surfaces of encrusting coralline algae. From the structure of the radula, it is evident that $A$. garnoti is capable of excavating coralline algae and this ability probably plays an important role in its dietary choice. Although not as effective as chitons, some limpets are capable of excavating the 
surfaces of coralline algae (Steneck, 1982; 1983; 1985; Steneck \& Watling, 1982). This still, however, does not explain the exceptionally low proportions of coralline algae in the gut of $C$. oculus despite having a radula very similar to $S$. cochlear (Figures 5).

X-ray analysis of the radulae of the limpets $S$. cochlear and $C$. oculus revealed very little differences in the relative amounts of iron in their functional teeth (Figure 5) and so the shape of the functional teeth may provide the answers to the limpets' excavation potential. Unlike $S$. cochlear's teeth that are rounded, blunt and shovellike with relatively broad ends that increase the area of contact with the substratum, the teeth of $C$. oculus are pointed, almost rake-like, with narrow ends that have a reduced area of contact with the substratum (Figure 5). Radulae with shovel-like, blunt teeth are known to be deeper excavators of encrusting coralline algae than those with rake-like, pointed teeth (Steneck \& Watling, 1982) and C. oculus is probably not as effective at excavating encrusting coralline algae as $S$. cochlear. Also, gut content analysis of $C$. oculus by Branch (1971) revealed a high proportion of encrusting fleshy algae, particularly $H$. lecanellierii (as an unidentifiable black paste) and $R$. verrucosa, both algae that we have shown to be high in organic content. Like $S$. cochlear, C. oculus may preferentially be consuming a mixture of algae but, unlike $S$. cochlear, may only be acquiring encrusting coralline algae in its diet through its foraging habit. A number of other grazers are known to perform best when foraging and maintaining mixed diets of intertidal algae, preferentially consuming mixtures of algae even when each of these foods is readily available (Kitting, 1980; Hagele \& Rowell-Rahier, 1999; Cruz-Rivera \& Hay, 2001; 2003). It may well be this grazing habit that reduces interspecific competition amongst foraging grazers but at the same time leads to high grazing frequencies.

\section{Conclusion}

It was previously suggested that fleshy algae are more nutritious than encrusting coralline algae (Branch, 1980). Our results have shown that this is not entirely true. The two corallines sampled (L. ferox and $S$. yendoi) are equally high in organic content compared to many other encrusting and turfy algae and even higher compared to many foliose algae. We have shown that encrusting coralline algae make up a large proportion of the diets of many intertidal grazers, some consuming more coralline algae than others. Those herbivores capable may be incorporating as much encrusting coralline algae in their diets, as they are generally high in organic content, and supplementing them with other seaweeds that may or may not be readily available. One certainty is that encrusting coralline algae play an important role in the diets of many intertidal herbivores. 


\section{Acknowledgements}

We thank the University of the Western Cape for providing funding, research equipment and space, the South African National Research Foundation for research grants to GWM and the International Ocean Institute of Southern Africa for study bursaries to DW and MP. Basil Julies and Gerald Malgas provided valuable assistance with the operation of the SEM and the X-ray analysis of the various herbivore radulae. A special thanks to Gordon Harkins and Verno Gordon for assistance with statistical analyses and field work respectively. 


\section{References}

Adey, W. H. \& I. G. McIntyre, 1973. Crustose coralline algae: A re-evaluation in the geological sciences. Geological Society of America Bulletin 84: 883-904.

Branch, G. M., 1971. The ecology of Patella Linnaeus from the Cape Peninsula, South Africa. I. Zonation, movements and feeding. Zoologica Africana 6: 1-38.

Branch, G. M., 1975. Mechanisms reducing intraspecific competition in Patella spp.: Migration, differentiation and territorial behaviour. Journal of Animal Ecology 44: 575-600.

Branch, G. M., 1976. Interspecific competition experienced by South African Patella species. Journal of Animal Ecology 45: 507-529.

Branch, G. M., 1980. Territoriality in limpets: Manipulation experiments and energy budgets. Journal of the Malacological Society of Australasia 4: 245-246.

Branch, G., 1985. Limpets: their role in littoral and sublittoral community dynamics. In Moore, P. G. \& R. Seed (eds.), The Ecology of Rocky Coasts. Hodder \& Stoughton Educational: 97-116.

Branch, G. M. \& M. Branch, 1988. The Living Shores of Southern Africa. Struik, Cape Town, $272 \mathrm{pp}$.

Branch, G. M. \& C. L. Griffiths, 1988. The Benguela Ecosystem part V. The coastal zone. Oceanography and Marine Biology. An Annual Review 26: 395-486.

Breitburg, D. L., 1984. Residual effects of grazing: Inhibition of competitor recruitment by encrusting coralline algae. Ecology 65: 1136-1143.

Cruz-Rivera, E. \& M. E. Hay, 2001. Macroalgal traits and the feeding and fitness of an herbivorous amphipod: the roles of selectivity, mixing and compensation. Marine Ecology Progress Series 218: 249-266.

Cruz-Rivera, E. \& M. E. Hay, 2003. Prey nutritional quality interacts with chemical defenses to affect consumer feeding and fitness. Ecological Monographs: 73: 483-506.

Dethier, M. N., 1994. The ecology of intertidal algal crusts: variation within a functional group. Journal of Experimental Marine Biology and Ecology 177: 3771.

Dethier, M. N., K. M. Paull \& M. M. Woodbury, 1991. Distribution and thickness patterns in subtidal encrusting algae from Washington. Botanica Marina 34: 201210.

Fretter, V. \& A. Graham, 1994. British Prosobranch Molluscs. Their functional anatomy and ecology. Ray Society, London, $820 \mathrm{pp}$.

Fujita, D.,1992. Grazing on the crustose coralline alga Lithophyllum yessoense by the sea urchin Strongylocentrotus nudus and the limpet Acmaea pallida. Benthos Research 42: 49-54.

Hagele, B.F. \& M. Rowell-Rahier, 1999. Dietary mixing in three generalist herbivores: nutrient complementation or toxin dilution? Oecologia 119: 521-533.

Keats, D. W. \& G. Maneveldt, 1994. Leptophytum foveatum Chamberlain \& Keats (Rhodophyta, Corallinales) retaliates against competitive overgrowth by other encrusting algae. Journal of Experimental Marine Biology and Ecology 175:243- 
251.

Keats, D. W., I. Matthews \& G. Maneveldt, 1994a. Competitive relationships and coexistence in a guild of crustose algae in the eulittoral zone, Cape Province, South Africa. South African Journal of Botany 60: 108-113.

Keats, D. W., P. Wilton \& G. Maneveldt, 1994b. Ecological significance of deep-layer sloughing in the eulittoral zone coralline alga, Spongites yendoi (Foslie) Chamberlain (Corallinaceae, Rhodophyta) in South Africa. Journal of Experimental Marine Biology and Ecology 175: 145-154.

Kitting, C. L., 1980. Herbivore-plant interactions of individual limpets maintaining a mixed diet of intertidal marine algae. Ecological Monographs 50: 527-550.

Littler, D. S. \& M. M. Littler, 2003. South Pacific Reef Plants: A divers' guide to the plant life of South Pacific Coral Reefs. Offshore Graphics Inc., Washington, 331 pp.

Littler, M. M., D. S. Littler \& P. R. Taylor, 1995. Selective herbivore increases biomass of its prey: A chiton-coralline reef-building association. Ecology 76: 1666-1681.

Lüning, K., 1990. Seaweeds. Their Environment, Biogeography and Ecophysiology. Wiley-Interscience, New York, 527 pp.

Mann, H. B. \& D. R. Whitney, 1947. On the test of whether one or two random variables is stochastically larger than the other. The Annals of Mathematics and Statistics 18: 50-60.

Maneveldt, G., 1995. Geographical studies on the interaction between the pear limpet, Patella cochlear, and the encrusting coralline alga, Spongites yendoi. Unpublished MSc thesis. University of the Western Cape, Bellville, South Africa, $154 \mathrm{pp}$.

Paine, R. T. 1984. Ecological determinism in the competition for space. Ecology 65: 1339-1348.

Paine, R. T. \& R. L. Vadas, 1969. The effects of grazing by the sea urchins, Strongylocentrotus spp. on benthic algal populations. Limnological Oceanography 14: 710-719.

Raffaelli, D. \& S. Hawkins, 1996. Intertidal Ecology. Chapman and Hall, London, $356 \mathrm{pp}$.

Sousa, W. P. \& J. H. Connell, 1992. Grazing and succession in marine algae. In John, D. M., S. J. Hawkins \& J. H, Price (eds), Plant-Animal Interactions in the Marine Benthos. Systematics Association Special Volume Number 46. The Systematics Association. Clarendon Press, Oxford: 425-441.

Stegenga, H., J. J. Bolton \& R. J. Anderson, 1997. Seaweeds of the South African West Coast. Contributions from the Bolus Herbarium, University of Cape Town, 18: $655 \mathrm{pp}$.

Steneck, R. S., 1982. A limpet-coralline alga association: Adaptations and defences between a selective herbivore and its prey. Ecology 63: 507-522.

Steneck, R. S., 1983. Escalating herbivory and resulting adaptive trends in calcareous crusts. Paleobiology 9: 44-61.

Steneck, R. S., 1985. Adaptations of crustose coralline algae to herbivory: Patterns in space and time. In Toomy, D. F. \& M. H. Nitecki (eds), Paleoalgology: 
Contemporary Research and Applications. Springer-Verlag, Berlin: 352-366.

Steneck, R. S., 1986. The ecology of coralline algal crusts: Convergent patterns and adaptive strategies. Annual Review of Ecological Systematics 17: 273-303.

Steneck, R. S. \& M. N. Dethier, 1994. A functional group approach to the structure of algal-dominated communities. Oikos 69: 476-498.

Steneck, R. S. \& L. Watling, 1982. Feeding capabilities and limitations of herbivorous molluscs: A functional group approach. Marine Biology 68: 299-319.

Steneck, R. S., S. D. Hacker \& M. N. Dethier, 1991. Mechanisms of competitive dominance between crustose coralline algae: An herbivore-mediated competitive reversal. Ecology 72: 938-950. 
Table 1. Taxa surveyed during the study and their main features.

\begin{tabular}{|c|c|c|c|}
\hline \multirow[b]{2}{*}{ Species } & \multicolumn{3}{|c|}{ Zone } \\
\hline & Main Feature & $\begin{array}{l}\text { occupie } \\
\text { d }\end{array}$ & Sub study \\
\hline Spongites yendoi (Foslie) Chamberlain & $\begin{array}{l}\text { Encrusting coralline red } \\
\text { alga }\end{array}$ & U \& L & *! \# \\
\hline Leptophytum foveatum ${ }^{1}$ Chamberlain \& Keats & $\begin{array}{l}\text { Encrusting coralline red } \\
\text { alga }\end{array}$ & $\mathrm{L}$ & $*$ \\
\hline $\begin{array}{l}\text { Leptophytum ferox (Foslie) Chamberlain \& } \\
\text { Keats }\end{array}$ & $\begin{array}{l}\text { Encrusting coralline red } \\
\text { alga }\end{array}$ & $\mathrm{U}$ & *! \# \\
\hline Hildenbrandia lecanellierii Hariot & Encrusting fleshy red alga & $\mathrm{U}$ & $* !$ \\
\hline Raflsia Verrucosa (Areschoug) J. Agardh & $\begin{array}{l}\text { Encrusting fleshy brown } \\
\text { alga }\end{array}$ & $\mathrm{U} \& \mathrm{~L}$ & * (in 'other')! \\
\hline Gelidium micropterum Kuetzing & $\begin{array}{l}\text { Turfy limpet-garden red } \\
\text { alga }\end{array}$ & $\mathrm{L}$ & *! \\
\hline Gelidium pristoides (Turner) Kuetzing & Turfy red alga & $\mathrm{U} \& \mathrm{~L}$ & $* !$ \\
\hline Porphyra capensis Kuetzing & Foliose red alga & $\mathrm{U}$ & * (in 'other')! \\
\hline $\begin{array}{l}\text { Gigartina polycarpa (Kuetzing) Setchell \& } \\
\text { Gardner }\end{array}$ & Foliose red alga & $\mathrm{L}$ & $* !$ \\
\hline Sarcothalia stiriata (Turner) Leister & Foliose red alga & $\mathrm{L}$ & * (in 'other')! \\
\hline Ulva capensis Areschoug & Foliose green alga & $\mathrm{U} \& \mathrm{~L}$ & *! \\
\hline Enteromorpha intestinalis (Linnaeus) Link & Foliose green alga & $\mathrm{U}$ & * (in 'other')! \\
\hline Cymbula oculus (Born) & Limpet - herbivore & $\mathrm{U}$ & $@+\$$ \\
\hline Siphonaria capensis Quoy \& Gaimard & False limpet - herbivore & $\mathrm{U}$ & $@+$ \\
\hline Scutellastra cochlear (Born) & $\begin{array}{l}\text { Gardening limpet } \\
\text { herbivore }\end{array}$ & $\mathrm{L}$ & $@+\$$ \\
\hline Acanthochiton garnoti ${ }^{2}$ (Blainville) & Chiton - herbivore & $\mathrm{U}$ & $+\$$ \\
\hline Oxystele variegata (Anton) & Winkle - herbivore & $\mathrm{U}$ & $@+$ \\
\hline
\end{tabular}


Tetraclita serrata Darwin

Barnacle

Octomeris angulosa Sowerby

Barnacle

$\mathrm{U}=$ Upper eulittoral zone; $\mathrm{L}=$ Lower eulittoral zone

* - Algal cover; ! - Organic content; @ - Density \& Biomass; \# - Grazing frequency; + - Gut contents; \$ - Radula anatomy

$1-L$. foveatum is extremely thin and near impossible to remove for organic content.

2 - A. garnoti was not observed on the exposed substratum during low tide but is known to graze coralline algae. 

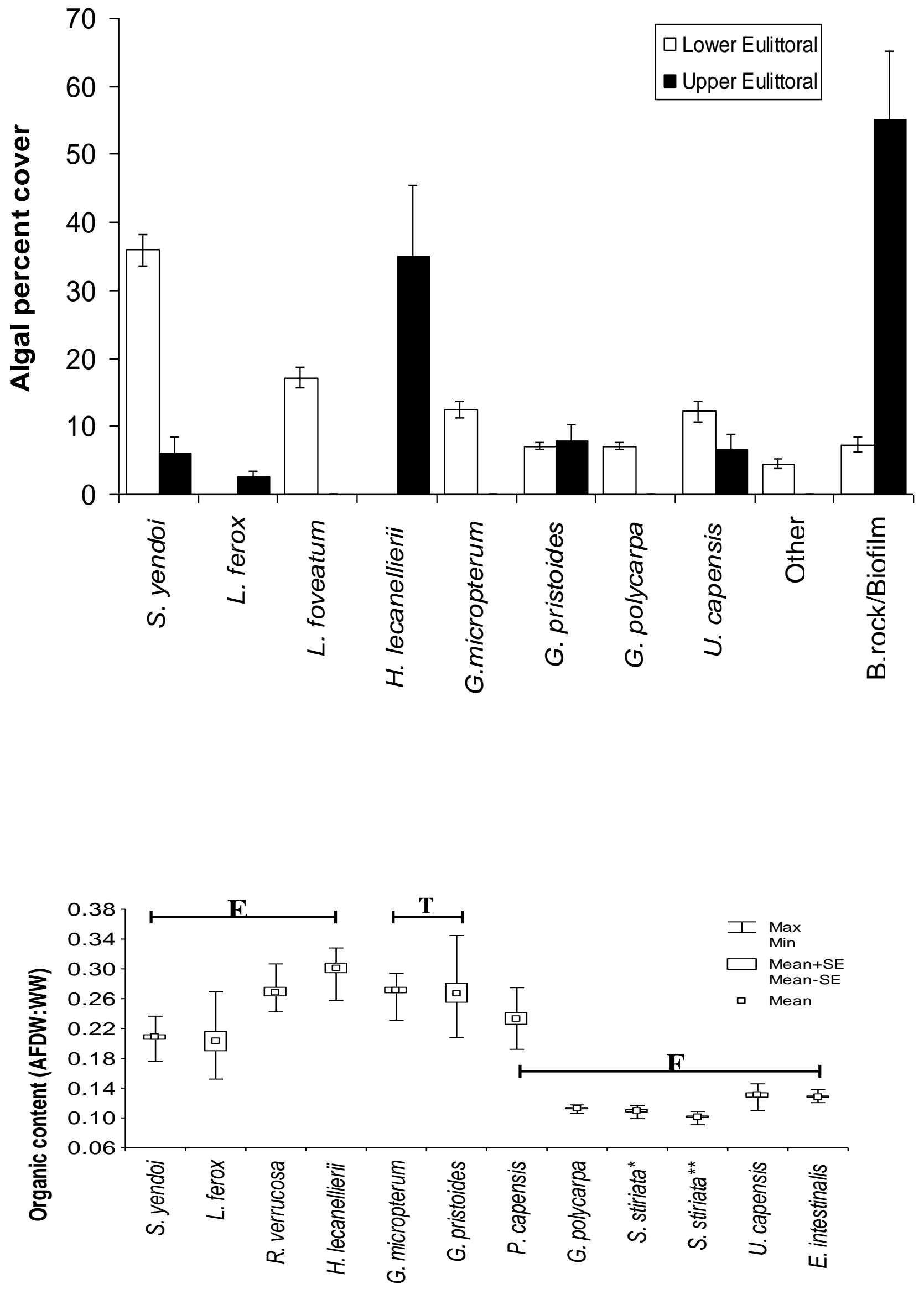
Table 2. Densities $\left(\mathrm{m}^{-2}\right)$ and biomass $\left(\mathrm{g} . \mathrm{m}^{-2}\right)$ of common invertebrates within the upper and lower eulittoral zones at Kalk Bay, South Africa.

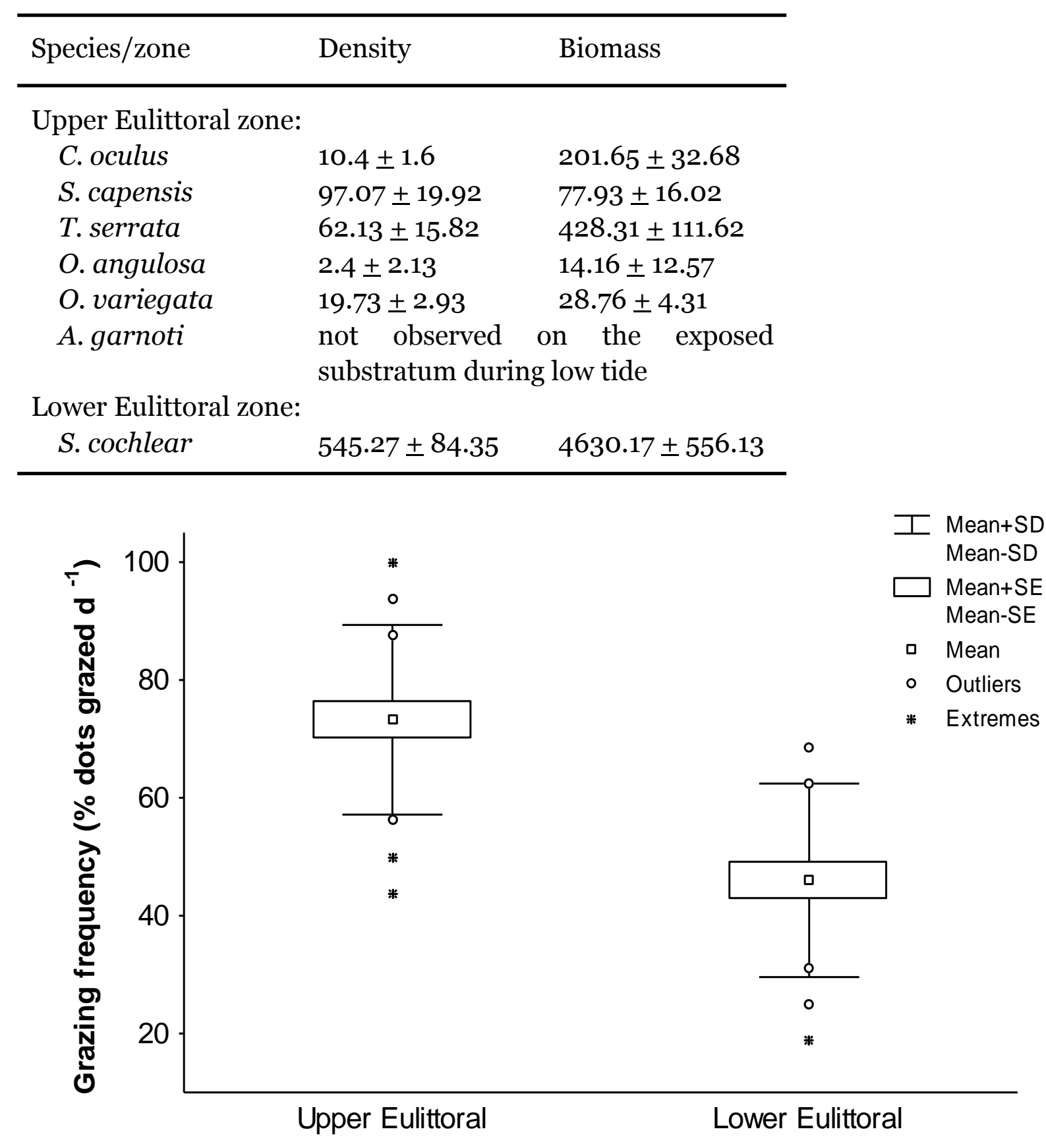




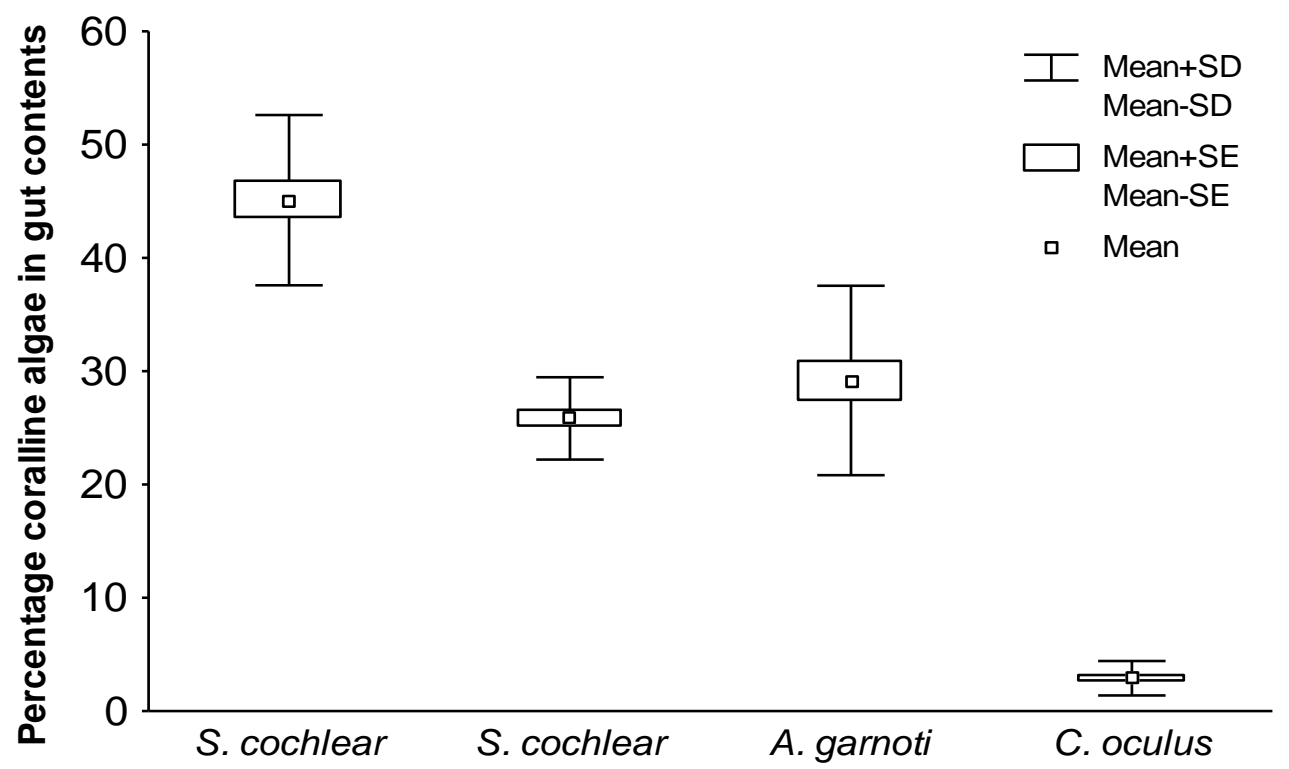



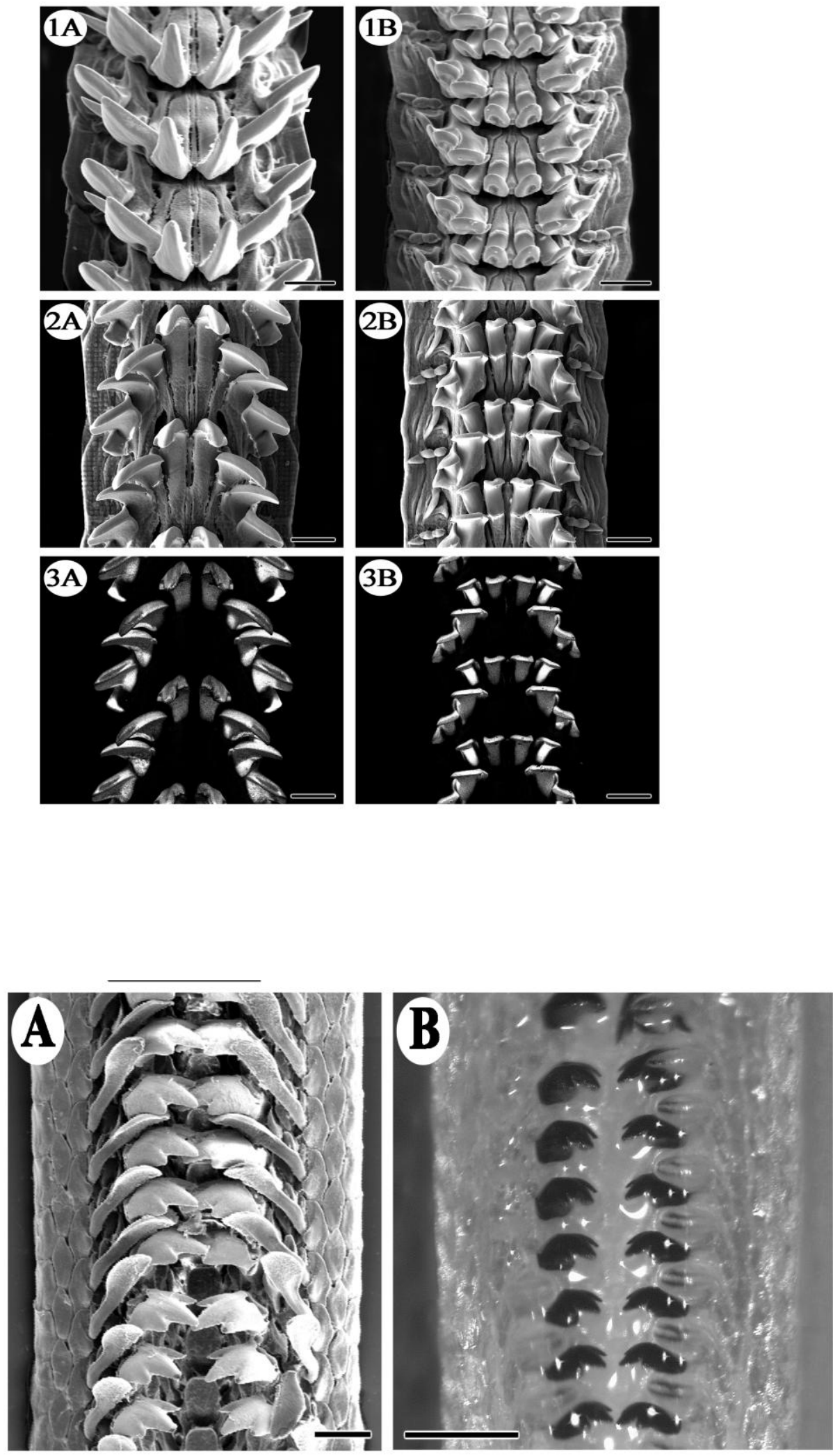